\title{
Determinant Analysis of Factors Influencing Tuak Consumption Culture on Guardian Earth Through the Leininger Model Sunrise Approach Theory
}

\author{
Wahyu Tri Ningsih ${ }^{1}$, Titik Sumiatin ${ }^{1}$ \\ ${ }^{1}$ Lecturer Department of NursingTuban Campus, Polytechnic of Health Ministry Surabaya
}

\begin{abstract}
People who consume alcoholic drinks in various regions in Indonesia, if viewed through the Sunrise Model approach, is influenced by several things, including technological factors, religious and philosophy of life factors, social and family relationships factors, cultural and styles life factors, policy and regulatory factors, economic factors and educational factors. The purpose of this research is to know the determinants of factors that influence the Culture of Tuak Consumption on Bumi Wali Tuban through the Leininger Model Theory Approach. The research design used in this study was analytic with a cross sectional approach. The population in this study are all residents in the area of Tuban Regency with a total of 1,291,665 people with a sample size of 400 taken using cluster sampling. Data was collected by using a questionnaire. The collected data was tabulated, analyzed using frequency distribution and percentage and presented in the distribution table. Analysis of bivariate and mutivariate data used logistic regression to find factor determinants. The results show that cultural values and lifestyle are the factors that most influence the culture of tuak consumption with $\mathrm{p}$ value $0.000(\mathrm{p}<0.05)$ and OR 23.11. This means that cultural and lifestyle factor have a chance of 23,11 times for someone to drink tuak. Tuak consumption in Tuban Regency is a culture that has declined and become a characteristic. This drink is "obligatory" and serves as a banquet for traditional events or traditional rituals in Tuban
\end{abstract}

Keywords: Consumption of tuak, Leininger's Sunrise Model Theory.

\section{Introduction}

As one of the drinks that contain alcohol, palm wine is also a favorite drink in various regions in Indonesia, especially in areas where Lontar trees grow, sap trees which are usually called sap can be processed into drinks which became known as "Tuak". Apart from Tuban, other areas that also have an old habit of consuming Batak, specifically the North Tapanuli region, Bali, South Sulawesi Toraja Tribe and Madura.

The results of the Demographic and Population Survey of Indonesia (IDHS) in 2012 also provided

\footnotetext{
Corresponding Author:

Wahyu Tri Ningsih

Dr. Wahidin SudiroHusodo Street No. 2 Tuban

e-mail: asyiranur@yahoo.com
}

information that the percentage of alcohol drinkers in men aged $15-19$ years was $30.2 \%$ and those aged $20-24$ years was $52.9 \%$, while the percentage of women aged $15-19$ years by $3.5 \%$ and aged $20-24$ years by $7.1 \%{ }^{(1)}$. Data on the number of consumers of Tuak and other types of alcoholic drinks in Tuban according to the District Health Office of Tuban is not clear. But in general, if we look at the daily life of the Tuban community, tuak has become a chatting partner for them. Every afternoon and evening the Tuban community has a habit of gathering, talking in groups, accompanied by a drink of wine. And it has become a hereditary culture in the city of Tuban since long ago.

The number of people who consume alcoholic beverages/palm wine in various regions in Indonesia when viewed through the Sunrise Model theory approach, namely the Transcultural approach, is influenced by several factors, including technological factors, religious 
factors and philosophy of life, social factors and family relationships, cultural factors and lifestyle, policy and regulatory factors that apply, economic factors and educational factors. From a health point of view the consumption of alcoholic drinks can also cause various diseases, and one of the diseases that often arise due to consuming alcoholic drinks/Tuak is Hypertension. Sesso also mentioned that there is a positive relationship between alcohol consumption and hypertension in both men and women ${ }^{(2)}$.

According to the Regional Regulations of Tuban No. 9 2016, alcoholic drinks are classified into three groups, namely: Group A is a drink with an ethyl alcoholic or ethanol content of up to $5 \%$, Group B is a beverage with an ethyl alcohol or ethanol content of $5 \%$ to $20 \%$, Group C is drinks with $20 \%$ to $55 \%$ ethyl alcohol or ethanol content. Tuak is an alcoholic beverage with $4 \%$ content. Based on the decisions and regulations that have been set, then tuak can be classified as one type of liquor class A.

In Tuban Tuak comes from sap of sap which is tapped from a siwalan tree or palm tree, which is accommodated in a bamboo "Bumbung" $40-50 \mathrm{~cm}$ long, and is stored for several days. The longer the storage, the higher the alcohol content it contains ${ }^{(3)}$.Diseases that can be caused by excessive alcohol consumption include: 1) Heart and blood vessel disease $\left.{ }^{(4)}, 2\right)$ diabetes mellitus, 3) kidney disease ${ }^{(5)},{ }^{(6)}$; 4) liver disease; 5) psychological $\operatorname{disorders}^{(7)}$.

The tradition of drinking palm wine has become a tradition of hereditary in Tuban. This drink is "mandatory" to exist and is a banquet at traditional events or traditional rituals in Tuban. It is not uncommon for Tuak to be a feast for young people when guests arrive from areas outside of Tuban. At the gathering we often encounter wine drinks in it, and also in Tuban there are not a few shops that sell this drink.

\section{Material and Method}

The research design used in this study was analytic with cross sectional approach. The population in this study were all residents in the Tuban Regency area with a total of 1,291,665 people. The sample in this study was a portion of the population in the Tuban Regency area. The inclusion criteria in this study were: population recorded in population data, male sex and adult age. The sample size in this study was 400 respondents. The sampling technique in this study was carried out by cluster sampling.

The dependent variable in this study is the culture of drinking wine. The independent variable in this study was taken from Leininger's Sunrise Model Theory, namely technological factors, religious and philosophical factors, social factors and family attachment, cultural and lifestyle factors, policy and regulatory factors, economic factors, Education factors. The instrument used in data collection was a questionnaire created by the researcher by developing the Sunrise Model theory. Statistical test uses logistic regression to analyze dominant factors.

\section{Result}

Respondent characteristics showed that all respondents were male, in the age range of 40 - 59 years $(66.50 \%)$, and most worked in the private sector $(41 \%)$ (table 1).

Table 1: Distribution of Respondent Characteristics

\begin{tabular}{|l|c|c|}
\hline Characteristics & n & \% \\
\hline Gender & & \\
Male & 400 & 100 \\
Female & 0 & 0 \\
\hline Age & & \\
$20-39$ years & 71 & 17,75 \\
$40-59$ years & 266 & 66,50 \\
$60-79$ years & 60 & 15 \\
$80-100$ yaers & 3 & 0,75 \\
\hline Employment & & \\
Does not work & 21 & 5,25 \\
Farmer & 139 & 34,75 \\
Fisherman & 5 & 1,25 \\
Entrepreneur & 58 & 14,5 \\
Private employees & 164 & 41 \\
Government employees & 13 & 3,25 \\
\hline
\end{tabular}

The results of the analysis using the logistic regression test showed that the technology variable obtained a regression coefficient of -20.038 with a significance level (r-value) of $0.998>0.005$. Technological factors do not significantly influence the culture of palm wine consumption in Bumi Wali Tuban. Religious variables obtained a regression coefficient of 1.069 with a significance level (r-value) of 0.344>0.005. Religious factors do not significantly influence the culture of palm wine consumption in Bumi Wali Tuban. Family variables obtained a regression coefficient of 19.030 with a level of significance (r-value) of $0.996>0.005$. Family factors do not significantly influence the culture of palm wine 
consumption in Bumi Wali Tuban. Variable values of culture and lifestyle obtained a regression coefficient of 3,150 with a significance level (value-value) of 0,000 $<0.005$. Lifestyle factors significantly influence the culture of palm wine consumption in Bumi Wali Tuban. The policy variable obtained a regression coefficient of 20,662 with a significance level (r-value) of 0.993> 0.005 . Policy factor does not significantly influence the culture of palm wine consumption in Bumi Wali Tuban. Economic variables obtained a regression coefficient of 0.227 with a level of significance (r-value) of $0.620>$
0.005 . Economic factors do not significantly influence the culture of palm wine consumption in Bumi Wali Tuban. The education variable obtained a regression coefficient of $-1,641$ with a significance level (r-value) of $0,000<0.005$. Educational factor significantly influences the culture of palm wine consumption in Bumi Wali Tuban. The factor of culture and lifestyle values is the most influential factor in the culture of drinking palm wine consumption with $\mathrm{p}$ value 0,000 ( $\mathrm{p}$ valuae $<0.05$ ) and OR 23,111. This means that lifestyle has a 23,111 chance for someone to drink wine. (table 2)

Table 2: Analysis of Factors influencing the culture of palm wine consumption in Bumi Wali Tuban June 2018

\begin{tabular}{|l|c|c|c|c|}
\hline \multirow{2}{*}{ Variable } & \multirow{2}{*}{ Sig. } & \multirow{2}{*}{$\operatorname{Exp}(\mathbf{B})$} & \multicolumn{2}{|c|}{$\mathbf{9 5 , 0 \%}$ C.I. for EXP (B) } \\
\cline { 4 - 5 } & & & Lower & Upper \\
\hline Technology & .998 & .000 & .000 & .317 \\
\hline Religion & .344 & 2.914 & .000 & 26.748 \\
\hline Family & .996 & $1.839 \mathrm{E} 8$ & 5.144 &. \\
\hline Cultural Value of Lifestyle & .000 & 23.343 & .000 &. \\
\hline Policy & .993 & $9.402 \mathrm{E} 8$ & .511 & 3.081 \\
\hline Economy & .620 & 1.255 & .107 & .503 \\
\hline Education & .000 & .232 & & \\
\hline Constant & .996 & .000 & & \\
\hline
\end{tabular}

\section{Discussion}

Research shows that almost all Tuban people are Muslim and religious factors do not significantly influence the culture of palm wine consumption in Bumi Wali Tuban. Adrianna Murphy in the article stated that Muslim women were less likely to drink alcohol than non-Muslims ${ }^{(8)}$. Research conducted by Khusnaini, states that there are differences of opinion between community leaders and religious leaders in addressing the circulation of tuak in Kaba Tuban Regency. Community leaders argue that tuak is not intoxicating, contains many benefits and by selling tuak can increase income. While religious leaders forbid tuak to be traded because it is included in intoxicating drinks (khamr) ${ }^{(9)}$.

The data states that the majority of Tuban residents are Muslim but the majority of them are palm wine consumers. They consume tuak for various reasons, among others, just because they want to drink, relieve stress, and to socialize when there are residents' activities. The results of the study stated that family factors did not affect the culture of palm wine consumption in Bumi Wali Tuban. Sobhee, S et al., In their study stated that, people who live in one house do not influence individuals to buy alcoholic drinks and the greater the number of family members the smaller expenditure on alcohol ${ }^{(10)}$. Research by Constantinescu, Maria, and Cornel Constantinescu, states that drinking alcohol behavior in addition to being influenced by personal choices is also influenced by the environment, for example legislation and friends ${ }^{(11)}$.

According to this research, according to the results of the study by Sobhee, S et al., They are not influenced by the family in consuming tuak. They live in an environment where most of the people are consumers of palm wine, so they are influenced to consume it. Consuming palm wine is common and easy to find in 
various places in Tuban. The factor of cultural value and lifestyle is the most influential factor on the consumption of palm wine in Bumi Wali Tuban. The study of Jennifer Ahern et al. States that environmental culture which is permissive to alcohol consumption influences individual alcohol consumption ${ }^{(12)}$. Research by Riskiyani et al. Shows that individuals understand tuak as a traditional alcoholic drink that has positive and negative effects on its consumption. Tuak is a beverage that can strengthen the brotherhood and is always served in celebration of traditional parties and daily activities, so that it has become a tradition in society. Residents present tuak as a typical drink to entertain visitors or guests, so that visitors or guests become accustomed to wine drinks ${ }^{(13)}$. The tuak consumption culture is a culture that has gone downhill in the Tuban region. This drink is "mandatory" to exist and is a banquet at traditional events or traditional rituals in Tuban. This study is in line with the results of the study above, that environmental culture influences a person to consume alcohol. So although most people think that drinking wine is a negative habit, but the culture of drinking wine still persists in the community for the reasons stated above.

The policy factor does not significantly influence the culture of palm wine consumption in Bumi Wali Tuban. Research by Constantinescu, Maria, and Cornel Constantinescu, states that drinking alcohol behavior in addition to being influenced by personal choices is also influenced by the environment, for example legislation and friends. This study also states that to reduce the consumption of alcoholic beverages, several policies need to be carried out, including: 1) Limiting the number of days and hours of sale, the density of certain locations or places where alcoholic drinks are sold; 2) Limiting alcohol consumption in public places. Prohibition of alcohol in certain areas in the city and at certain times. Promote physical security and social order; 3) limiting alcohol marketing and promotional prices, especially marketing and promoting alcohol intended for young people; 4) Promote consumption of soft drinks, by setting prices lower than the cheapest alcoholic drinks; 5 ) restrictions on the sale of alcohol near schools ${ }^{(11)}$.

Explicitly, the regulation does not regulate traditional drinks containing alcohol such as wine. The Tuban District Government also does not prohibit the sale of palm wine. Because producing palm wine is one of the economic sources of citizens. To reduce the impact of excessive drinking there is an appeal from the government to sell wine in areas far from the crowd, so that people who are drunk do not make a fuss. Besides being a source of income, tuak is also a tradition that has been passed down in the community.

Economic factors do not significantly influence the culture of palm wine consumption in Bumi Wali Tuban. Rafferty, Ellen, in her study said that, as individual income levels increase, the estimated opportunities for engaging in alcohol consumption also increase. Individuals with higher incomes tend to drink more often than low income earners ${ }^{(14)}$. Sobhee's research, S, also states that spending to buy alcohol by alcohol dependent individuals increases when income rises. Income is the main determinant of spending on alcohol by individuals who are alcohol dependent ${ }^{(10)}$.

The education factor significantly influences the culture of palm wine consumption in Bumi Wali Tuban. Rafferty, Ellen, in the results of the study stated that, individuals with less education than secondary school had a 1.09 times higher chance than individuals with education after secondary school ${ }^{(14)}$. Anamaria Ciubară's research also states that the level of education also influences general attitudes toward alcoholism and alcoholism, subjects with higher education are far more aware of the negative effects of alcoholism than subjects with less educational levels ${ }^{(15)}$.Low education factor makes it difficult for someone to accept new information, in this case is information about wine and its effects, even though they argue that drinking wine is a negative habit.

\section{Conclusion}

The factor of cultural value and lifestyle is the most influential factor in the culture of consumption of palm wine, the cultural value and lifestyle has a 23.1 times chance for someone to drink wine .In accordance with Leininger's Sunrise Model theory approach, what needs to be done is to help clients adapt to certain cultures that are more beneficial to health (negotiation) and cultural restructuring, namely by periodically providing counseling about the dangers of alcoholic beverages to the community in communities and adolescents in schools.

Conflict of Interest: There is no conflict of interest to be declared.

\section{Source of Funding: None}

Ethical Clearance: This study was approved by 
thehealth research ethics commission Health Polytechnic Ministry of Health No. 155/S/KEPK/V/2018.

\section{References}

1. Badan Pusat Statistik. Survei Demografi dan Kesehatan Indonesia 2012. Jakarta: Badan Pusat Statistik; 2013.

2. Sesso HD, Cook NR, Buring JE, Manson JE, Gaziano JM. Alcohol Consumption and the Risk of Hypertension in Women and Men. Hypertension. 2008;51(4):1080-7.

3. Pradnyandari AAAT, Dhyanaputri IGAS, Jirna IN. Kajian Karakteristik Objektif Dan Subjektif Tuak Aren (Arenga Pinnata) Berdasarkan Lama Waktu Penyimpanan. Meditory. 2017;5(2):13-22.

4. Teo AST, Kapantow NH, Malonda NSH. Pengaruh Pemberian Virgin Coconut Oil (Vco) Terhadap Kadar Trigliserida Penderita Diabetes Melitus Di BLU RSUP Prof. Dr. R. D. Kandou Manado. Universitas Sam Ratulang iManado; 2013.

5. Putra A. Pengaruh Alkohol terhadap Kesehatan. Pros Semin Nas FMIPA. 2012;

6. Yamagata K, Ishida K, Sairenchi T, Takahashi $\mathrm{H}$, Ohba S, Shiigai $\mathrm{T}$, et al. Risk factors for chronic kidney disease in a community-based population : a 10-year follow-up study. Kidney Int. 2007;71(2):159-66.

7. Utina SS. Alkohol dan Pengaruhnya terhadap k Kesehatan Mental. J Heal Sport. 2012;5(2).

8. Murphy A, Roberts B, Stickley A, Mckee M. Social Factors Associated with Alcohol Consumption in the Former Soviet Union : A Systematic Review. Alcohol Alcohol. 2012;47(6):711-8.

9. Khusnaini PM. Pandangan Tokoh Agama Dan Tokoh Masyarakat Terhadap Peredaran Jual Beli "Tuak" Di Kabupaten Tuban Jawa Timur. skripsi. 2016;

10. Sobhee S, Kasseeah $\mathrm{H}$, Tandrayen-ragoobur V, Gopaul A. An empirical analysis of the determinants of expenditure on alcohol by alcohol dependent individuals in Mauritius. Grugs and Alcohol Today. 2015;15(3):158-72.

11. Constantinescu M, Constantinescu C. Success local policies in preventing and reducing the alcohol consumption among youngters. Rev Cercet si Interv Soc. 2012;36:54-73.

12. Ahern J, Galea S, Hubbard A, Midanik L, Syme SL. Original Contribution " Culture of Drinking " and Individual Problems with Alcohol Use. Am J Epidemiol. 2008;167(9):1041-9.

13. Riskiyani S, Jannah M, Rahman A. Aspek Sosial Budaya Pada Konsumsi Minuman Beralkohol (Tuak) Di Kabupaten Toraja Utara/The Social Culture Aspect of Alcohol (Tuak) Used In North Toraja. Media Kesehat Masy Indones Indones J Public Heal. 2015;11(2):76-85.

14. Rafferty E, Ian W, Bonner A, Code J, Mcbride $\mathrm{K}$, Andkhoie M, et al. Factors influencing risky single occasion drinking in Canada and policy implications. Arch Public Heal. 2017;75(22):1-11.

15. Ciubar A, Burlea L, Irina S, Radu DA, U RC. Alcohol addiction - a psychosocial perspective. Procedia - Soc Behav Sci. 2015;187:536-40. 